\title{
Rancang Bangun Kapasitor Bank Otomatis Berbasis Mikrokontroler ATmega 328P Untuk Perbaikan Faktor Daya
}

\author{
Putu Angga Juliantara ${ }^{1}$, I Wayan Arta Wijaya ${ }^{2}$, Cok Gede Indra Partha ${ }^{3}$ \\ Program Studi Teknik Elektro, Fakultas Teknik, Universitas Udayana Denpasar - Bali \\ Email : putuanggajuliantara@gmail.com ${ }^{1}$, artawijaya@unud.ac.id $^{2}$, cokindra@unud.ac.id $^{3}$
}

\begin{abstract}
Abstrak
Beban induktif dengan faktor daya rendah menyebabkan arus beban semakin besar sehingga dibutuhkan perbaikan faktor daya. Perbaikan faktor daya pada beban induktif dapat dilakukan dengan cara memasang kapasitor sesuai nilai yang dibutuhkan. Pemasangan kapasitor dapat dilakukan dengan cara paralel atau seri terhadap sumber listrik. Metode perancangan dibagi menjadi dua bagian yaitu, pertama perancangan perangkat keras (hardware) dan yang kedua perancangan perangkat lunak (software). Perancangan hardware terdiri dari perancangan rangkaian catu daya, rangkaian driver relay, rangkaian LCD, rangkaian sistem minimum ATmega 328P, rangkaian kapasitor bank, rangkaian sensor arus dan rangkaian sensor tegangan. Sensor yang digunakan pada penelitian ini menggunakan sensor arus tipe non-invasive SCT013-010 dan sensor tegangan menggunakan transformator tipe nol $500 \mathrm{~mA}$. Perancangan software berupa program kerja alat yang menggunakan aplikasi Arduino IDE. LCD menampilkan nilai pembacaan input tegangan, arus beban, daya aktif, daya semu, daya reaktif dan faktor daya. Mikrokrontroler ATmega 328P mengolah data dan menentukan relay yang bekerja sehingga tujuan nilai faktor daya dengan cos phi $\geq 0,85$ tercapai. Hasil yang dicapai dalam penelitian ini adalah rancang bangun kapasitor bank otomatis berbasis mikrokontroler ATmega 328P dapat memperbaiki faktor daya dengan melakukan injection capacitor untuk menaikkan nilai faktor daya sesuai standar PLN dengan cos phi $\geq 0,85$ dengan menghubungkan kapasitor ke sumber jala-jala listrik PLN yang diparalel dengan beban induktif satu fasa.
\end{abstract}

Kata Kunci : Mikrokontroler ATmega 328P, Faktor Daya, Kapasitor Bank, Beban Induktif.

\section{Abstract}

Inductive load with low power factor has led to the greater load current so that it is required a power factor improvement. Improvement of power factor in inductive load can be carried out by installing capacitor according to required proportion. Installation of capacitors can be used in parallel or series to electric source. The method of making design is divided into two parts, namely, the first is the designing of hardware and the second is the designing of the software. The designing of hardware consists of designing the power supply circuit, driver relay circuit, LCD circuit, minimum system circuit of ATmega 328P, capacitor bank circuit, current sensor circuit and voltage sensor circuit. The sensors used in this study were a non-invasive type SCT013-010 current sensor and a voltage sensor of a 500 mA type zero transformer. The design of software was in the form of work program tools that use the application of Arduino IDE. LCD displays the readout values of voltage, load current, active power, apparent power, reactive power and power factor. The ATmega 328P microcontroller processes data and determines the working relay so that the purpose of power factor value by cos phi $\geq 0.85$ is achieved. The results achieved in this research is the design of automatic bank capacitor based on microcontroller of ATmega 328P can improve power factor by conducting injection capacitor to raise the power factor value according to PLN standard by cos phi $\geq 0.85$ by connecting capacitor to the source of PLN paralleled by a single phase inductive load.

Keywords: Microcontroller of ATmega 328P, Power Factor, Capacitor Bank, Inductive Load.

\section{PENDAHULUAN}

Pelanggan tenaga listrik rumah tangga lebih banyak menggunakan beban induktif. Penggunaan beban induktif yang masih sering dapat dilihat di rumah tangga meliputi pompa air dan lampu TL. Penggunaan beban induktif berdampak pada faktor daya. Nilai faktor daya yang rendah dibawah 0,85 dapat diperbaiki dengan salah satu cara memasang kompensasi kapasitif menggunakan komponen kapasitor. Komponen kapasitor sebagai pembangkit daya reaktif berfungsi untuk menyeimbangkan kebutuhan daya reaktif beban induktif [1].

Pada penelitian yang sudah dilakukan untuk perbaikan power factor konsumen rumah tangga menggunakan kapasitor bank. Pemasangan kapasitor bank dirangkai paralel 
terhadap sumber jala-jala PLN. Hasil perbaikan faktor daya setelah pemasangan kapasitor bank didapat tidak kurang dari 0,85 sesuai standar PLN [2].

Selain dari penelitian diatas, penelitian yang terkait perbaikan faktor daya dengan judul perancangan kebutuhan kapasitor bank untuk perbaikan faktor daya pada Line Mess I di PT. Bumi Lamongan Sejati. Perancangan kebutuhan kapasitor bank dilakukan dengan menentukan lokasi pemasangan instalasi kapasitor bank. Pemasangan kapasitor bank di Line Mess I di PT. Bumi Lamongan Sejati dilakukan dengan cara individual compensation untuk memperbaiki faktor daya beban [3].

Berdasarkan dari kedua penelitian yang sudah dilakukan, pada penelitian ini dibuatlah sebuah alat yang dapat memperbaiki faktor daya secara otomatis dengan beban induktif 1 fasa. Cara kerja alat ini memperbaiki faktor daya $\leq 0,85$ dengan melakukan injection capacitor yang terhubung paralel terhadap beban induktif 1 fasa.

Mikrokontroler ATmega 328P berfungsi untuk mengontrol injection capacitor dan sebagai pengolah data sensor yang didapat dari sensor tegangan dan sensor arus. Sensor yang digunakan pada penelitian ini menggunakan sensor arus tipe non-invasive SCT013-010 dan sensor tegangan menggunakan transformator step down tipe nol $500 \mathrm{~mA}$. LCD 20x4 sebagai media interface untuk menampilkan tegangan $A C$, arus $A C$, daya reaktif beban induktif 1 fasa dan faktor daya.

\section{KAJIAN PUSTAKA}

\subsection{Daya Aktif}

Daya aktif adalah daya yang digunakan komponen pasif resistor yang merupakan daya terpakai [4].

Persamaan daya aktif dapat dirumuskan sebagai berikut [4] :

$$
P=V \cdot I \cdot \cos \cdot \varphi
$$

Keterangan :

$P$ adalah Daya Aktif $(W)$

$V$ adalah Tegangan $(V)$

$I$ adalah Arus (A)

$\varphi$ adalah Sudut Fasa $\left({ }^{\circ}\right)$

\subsection{Daya Reaktif}

Persamaan daya reaktif dapat dirumuskan sebagai berikut [4] :

$$
Q=V \cdot I \cdot \sin \cdot \varphi
$$

Keterangan :

$Q$ adalah Daya Reaktif (VAR)
$V$ adalah Tegangan $(V)$

$I$ adalah Arus (A)

$\varphi$ adalah Sudut Fasa ( ${ }^{\circ}$ )

\subsection{Daya Semu}

Daya semu adalah hasil perkalian antara tegangan dengan arus. Satuan dari daya semu adalah volt ampere (VA) [4].

Persamaan daya semu dapat dirumuskan sebagai berikut [4] :

$$
S=V . I
$$

Keterangan :

$$
S \text { adalah Daya Semu (VA) }
$$

$V$ adalah Tegangan ( $V$ )

I adalah Arus (A)

\subsection{Faktor Daya}

Faktor daya adalah perbandingan antara data aktif (W) dengan daya semu (VA) dinyatakan dalam $\cos \varphi$ atau disebut dengan Power Factor (PF) [4].

Secara matematika faktor daya dirumuskan sebagai berikut [4] :

$$
P F=\frac{P}{S}=\frac{V \cdot I \cdot \cos \varphi}{V \cdot I}=\cos \varphi
$$

Keterangan :

$$
\begin{array}{ll}
P F & \text { adalah Power Factor } \\
P & \text { adalah Daya Aktif (W) } \\
S & \text { adalah Daya Semu (VA) }
\end{array}
$$

\subsection{Perbaikan Faktor Daya}

Perbaikan faktor daya bertujuan untuk menaikkan nilai $\cos \varphi$ yang rendah sampai tercapainya standar nilai cos phi sebesar 0,85. Perbaikan faktor daya dapat dilakukan dengan memasang nilai kapasitor yang dibutuhkan [5]. Prinsip perbaikan faktor daya dapat ditunjukkan pada Gambar 1.

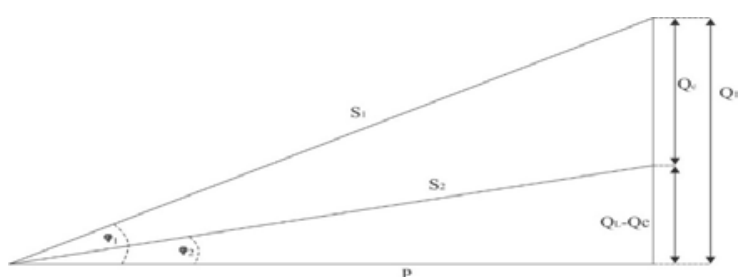

Gambar 1. Prinsip Perbaikan Faktor Daya [6]

Perhitungan perbaikan faktor daya berdasarkan referensi buku Lesson In Circuit Volume II - AC dengan menggunakan kapasitor dibagi menjadi tiga tahap meliputi perhitungan faktor daya tanpa menggunakan kapasitor, perhitungan kapasitor yang dibutuhkan untuk perbaikan faktor daya dan perhitungan faktor daya menggunakan kapasitor [7]. 
Persamaan dari 5 sampai 7 adalah perhitungan faktor daya tanpa menggunakan kapasitor sebagai berikut [7] :

$$
\begin{aligned}
P & =\operatorname{Vin} \cdot I \cdot \cos \cdot \varphi \\
S_{1} & =\operatorname{Vin} \cdot I \\
P F_{1} & =\frac{P}{s_{1}}
\end{aligned}
$$

Persamaan dari 8 sampai 10 adalah perhitungan kapasitor yang dibutuhkan untuk perbaikan faktor daya sebagai berikut [7] :

$$
\begin{aligned}
& Q_{1}=\sqrt{S^{2}-P^{2}} \\
& X_{c}=\frac{\operatorname{Vin}^{2}}{Q_{1}} \\
& C=\frac{1}{2 \cdot \pi \cdot f \cdot x_{C}}
\end{aligned}
$$

Persamaan dari 11 sampai 16 adalah perhitungan faktor daya menggunakan kapasitor sebagai berikut [7] :

$$
\begin{aligned}
X_{C} & =\frac{1}{2 \cdot \pi \cdot f \cdot C} \\
I_{2} & =\frac{V i n}{X_{C}} \\
Q_{\text {capactif }} & =\frac{V_{\text {Vin }^{2}}}{X_{C}} \\
Q_{\text {total }} & =Q_{\text {inductif }}-Q_{\text {capacitif }} \\
S_{2} & =\sqrt{Q_{\text {total }}^{2}+P^{2}} \\
P F_{2} & =\frac{P}{S_{2}}
\end{aligned}
$$

Keterangan :

$P \quad$ adalah Daya Nyata (W)

$V_{\text {in }} \quad$ adalah Tegangan Input $(V)$

$S_{1} \quad$ adalah Daya Semu Lama (VA)

$\mathrm{S}_{2}$ adalah Daya Semu Baru (VA)

$Q_{1}$ adalah Daya Reaktif Lama (VAR)

$Q_{c} \quad$ adalah Daya Reaktif kapasitor (VAR)

$Q_{\text {total }}$ adalah Total Daya Reaktif (VAR)

$\mathrm{PF}_{1}$ adalah Power Factor Lama

$\mathrm{PF}_{2}$ adalah Power Factor Baru

$C$ adalah Kapasitor $(\mu F)$

$I_{2} \quad$ adalah Arus baru $(A)$

$f \quad$ adalah Frekuensi $(\mathrm{Hz})$

$\varphi \quad$ adalah Sudut Fasa $\left({ }^{\circ}\right)$

$\pi \quad$ adalah 3,14

\subsection{Kapasitor Bank}

Kapasitor bank adalah rangkaian yang terdiri dari beberapa unit kapasitor yang terhubung secara seri atau paralel yang digunakan untuk memberikan kompensasi daya reaktif. Instalasi kapasitor bank dibagi menjadi 3 (tiga) bagian yaitu global compensation, group compensation, dan individual compensation seperti ditunjukkan pada Gambar 2.

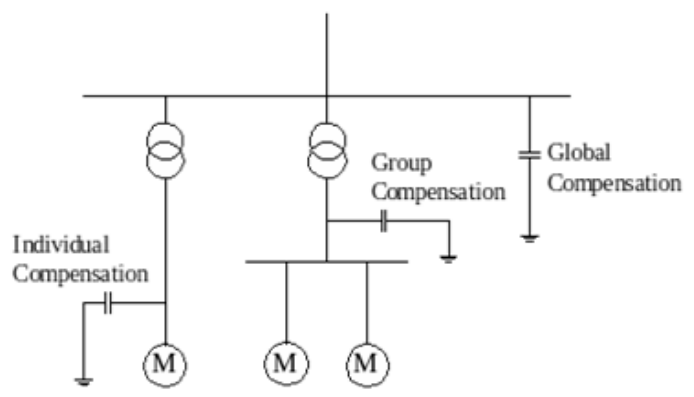

Gambar 2. Instalasi Kapasitor Bank [8]

\subsection{Arduino}

Arduino IDE (Intergrated Development Enviroment) merupakan aplikasi mikrokontroler yang dapat melakukan edit, compile, dan upload code ke modul arduino. Arduino IDE dapat digunakan untuk melakukan burning bootloader ke mikrokontroler. Burning bootloader berfungsi melakukan pemetaan fungsi port ATmega sesuai dengan sistem arduino [9].

\section{METODELOGI PENELITIAN}

Metode penelitian pada rancang bangun kapasitor bank otomatis berbasis mikrokontroler ATmega 328P untuk perbaikan faktor daya sebagai berikut :

1. Melakukan pengukuran faktor daya, tegangan dan arus untuk beban lampu TL yang akan diujikan.

2. Studi literatur dengan mengumpulkan dan mempelajari data-data yang bersumber dari jurnal dan buku sesuai dengan penelitian.

3. Perancangan hardware bertujuan untuk merancang rangkaian dan kebutuhan komponen yang diperlukan.

4. Perancangan software bertujuan untuk merancang program yang digunakan dalam perbaikan faktor daya.

5. Proses pengujian dilakukan untuk mengetahui program dan alat bekerja dengan baik dan benar.

\subsection{Metode Perancangan Hardware}

Metode perancangan hardware meliputi rangkaian sistem mikrokontroler ATmega 328P, rangkaian driver relay, rangkaian sensor arus, rangkaian sensor tegangan, rangkaian sensor LCD 20x4, rangkaian kapasitor bank dan rangkaian catu daya. 


\subsubsection{Rangkaian Sistem Minimum Mikrokontroler \\ Rangkaian sistem minimum} mikrokontroler menggunakan ATmega 328P yang sudah dilakukan burning boatloader. Rangkaian sistem minimum mikrokontroler ATmega 328P ditunjukkan pada Gambar 3.

\subsubsection{Rangkaian Driver Relay}

Rangkaian driver relay berfungsi sebagai buffer antara mikrokontroler dengan relay karena output arus yang dihasilkan oleh mikrokontroler tidak dapat digunakan secara langsung untuk mengoperasikan relay. Rangkaian driver relay dapat ditunjukkan pada Gambar 4.

\subsubsection{Rangkaian Sensor Arus}

Rangkaian sensor arus AC berfungsi untuk mendeteksi besarnya nilai arus yang mengalir ke beban pada suatu kawat penghantar. Sensor arus yang digunakan SCT013-010 dengan kemampuan pengukuran arus maksimal $10 \mathrm{~A}$. Rangkaian sensor arus ditunjukkan pada Gambar 5.

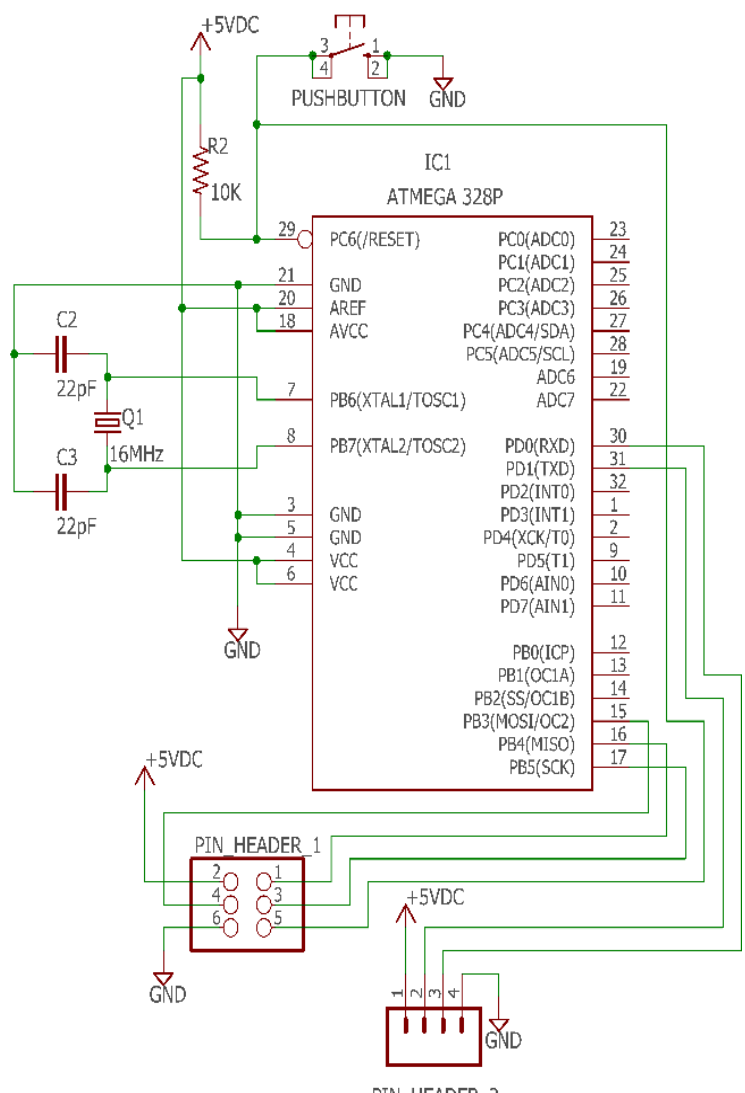

PIN_HEADER_2

Gambar 3. Rangkaian Sistem Minimum Mikrokontroler ATmega 328P

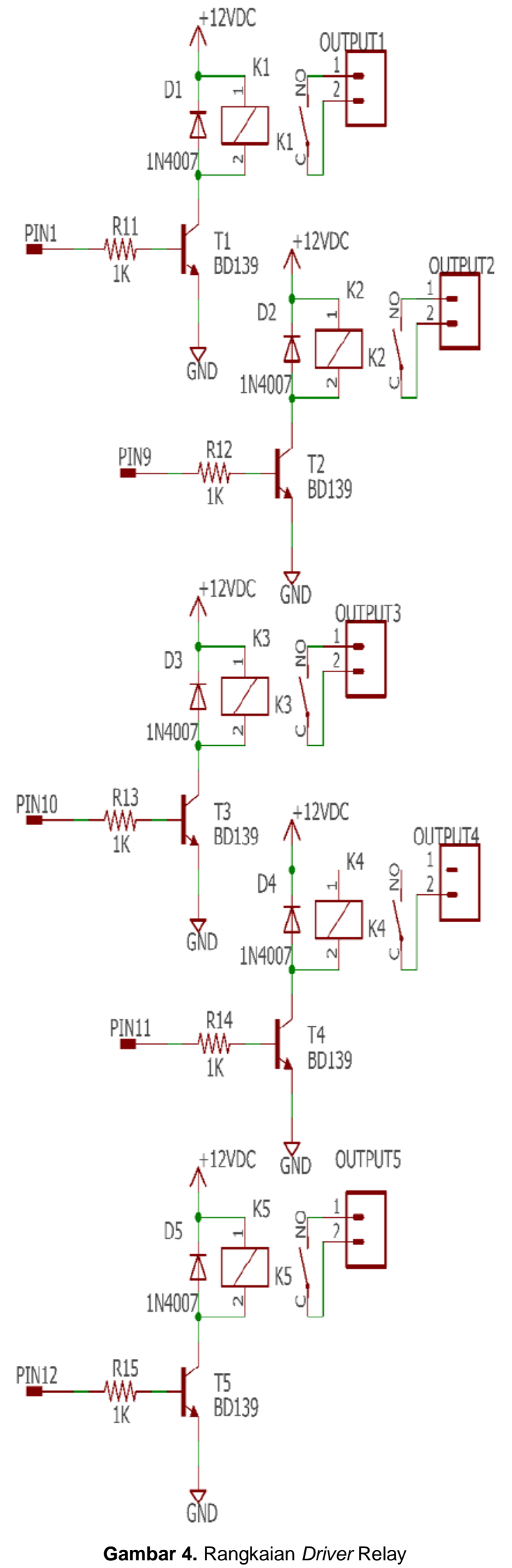

3.1.4. Rangkaian Sensor Tegangan 
Rangkaian sensor tegangan pada arus bolak-balik menggunakan transformator step down tipe nol dengan arus $500 \mathrm{~mA}$ dengan input primer transfromator 220 VAC dan output sekunder transformator 12 VAC. Rangkaian sensor tegangan ditunjukkan pada Gambar 6.

\subsubsection{Rangkaian Kapasitor Bank}

Rangkaian kapasitor bank terhubung paralel dengan sumber tegangan 220 VAC. Rangkaian kapasitor bank ditunjukkan pada Gambar 7.

\subsubsection{Rangkaian LCD $20 \times 4$}

Rangkaian LCD menggunakan LCD 20x4 dengan rincian 4 baris dan 20 kolom untuk setiap baris. Rangkaian LCD 20x4 ditunjukkan pada Gambar 8.

\subsubsection{Rangkaian Catu Daya}

Rangkaian catu daya pada alat ini berfungsi untuk mensuplai tegangan sesuai yang dibutuhkan rangkaian sistem minimum mikrokontroler ATmega 328P, LCD, sensor tegangan, sensor arus dan driver relay. Rangkaian catu daya dapat ditunjukkan pada Gambar 9.

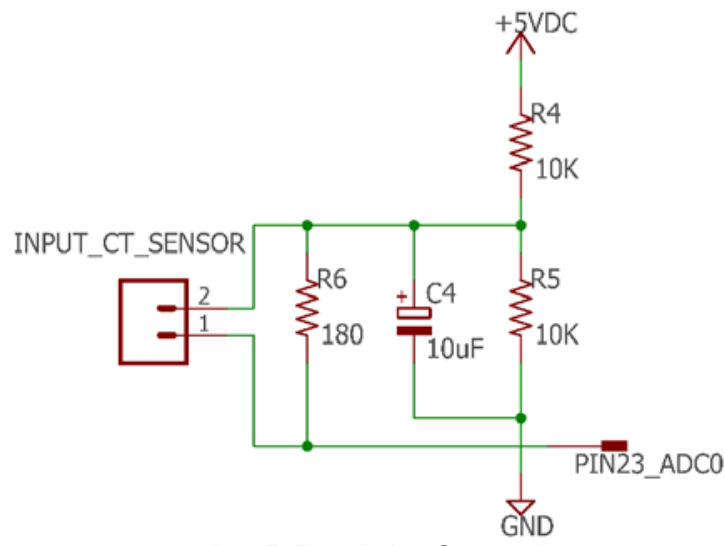

Gambar 5. Rangkaian Sensor Arus

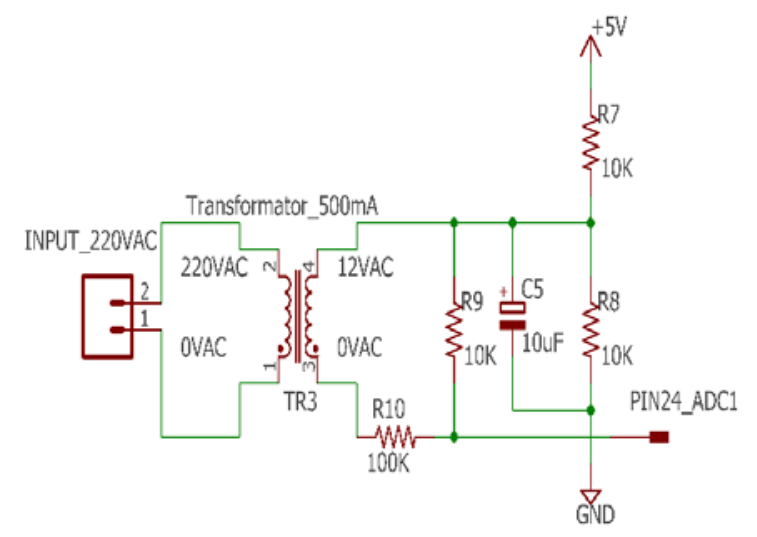

Gambar 6. Rangkaian Sensor Tegangan

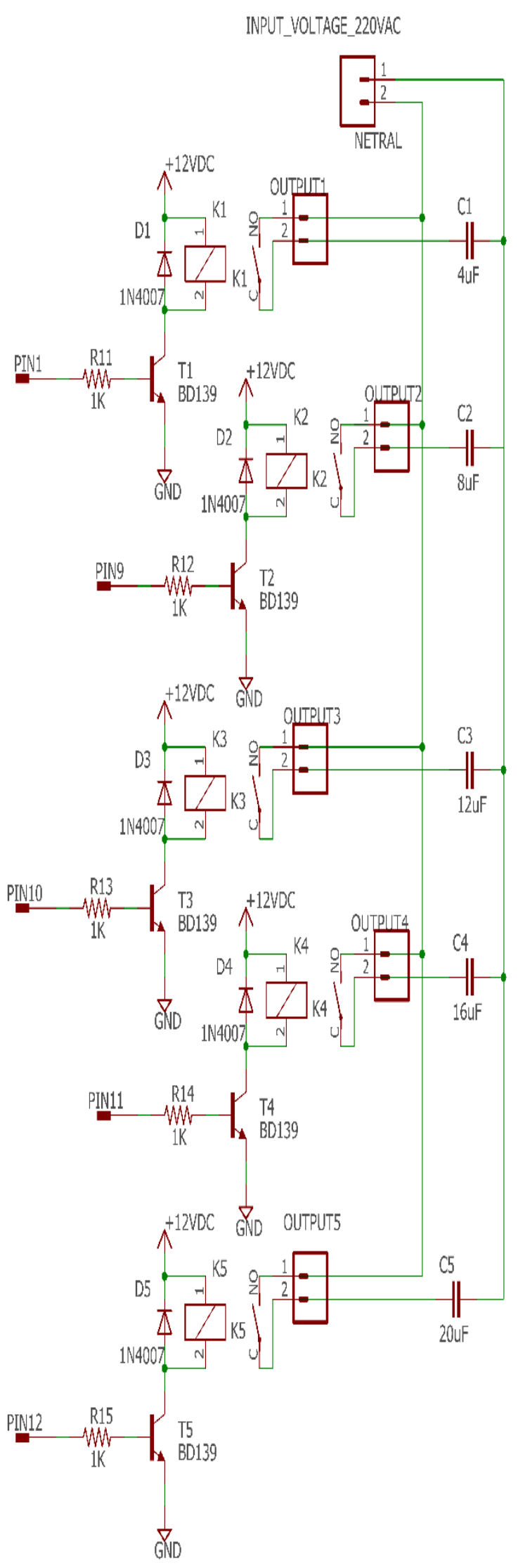

Gambar 7. Rangkaian Kapasitor Bank 


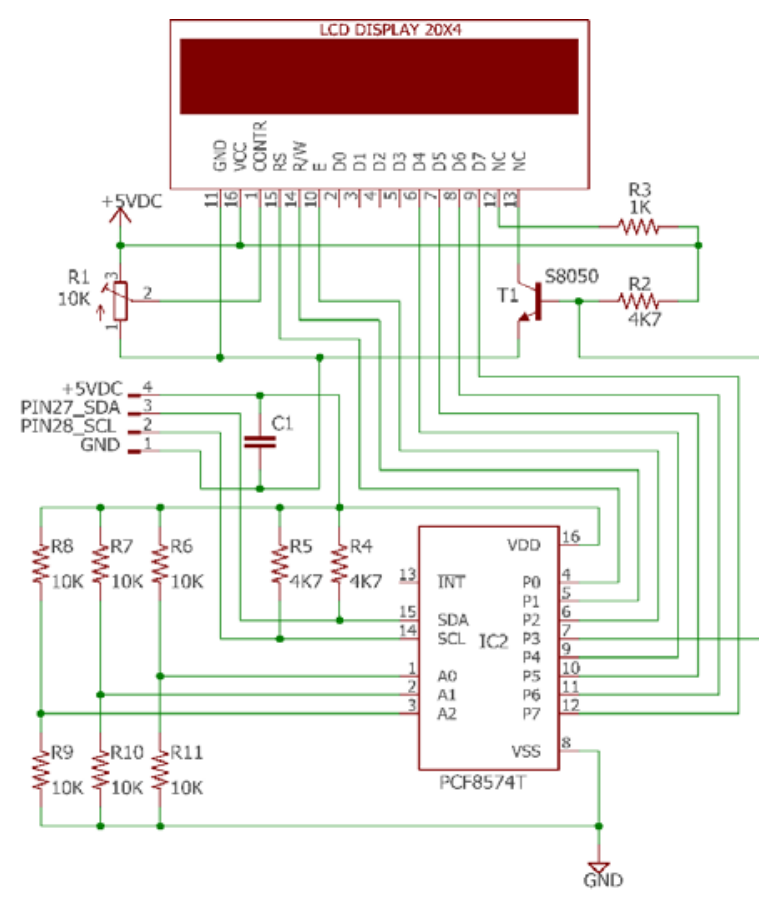

Gambar 8. Rangkaian LCD 20x4

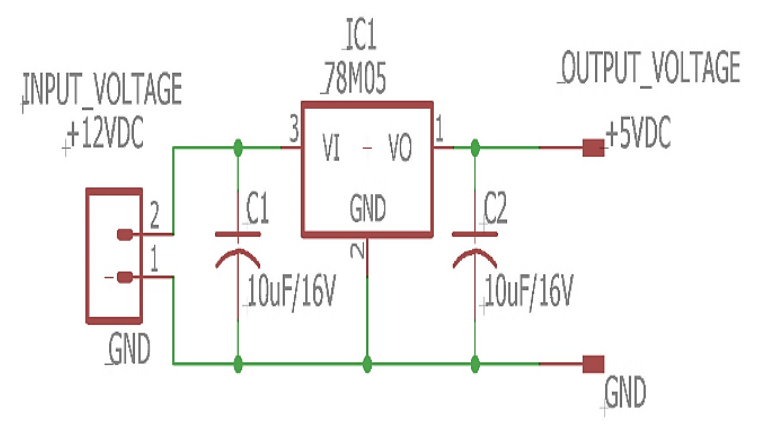

Gambar 9. Rangkaian Catu Daya

\subsection{Metode Perancangan Software}

Metode perancangan software menggambarkan proses kerja sistem perbaikan faktor daya dengan menggunakan kapasitor bank berbasis mikrokontroler ATmega 328P. Penjelasan metode perancangan software sebagai berikut :

1. Melakukan instruksi untuk inisial port LCD, sensor tegangan, sensor arus, dan driver relay sesuai urutan program yang dibuat.

2. Melakukan insialisasi data awal meliputi tegangan $A C(V)$, arus $(I)$, daya aktif $(P)$, daya semu (S), daya reaktif (Q), faktor daya (PF).

3. Data input arus didapat dari pembacaan sensor arus SCT013-010 dan data input tegangan didapat dari pembacaan sensor tegangan menggunakan transformator.

4. Melakukan perhitungan daya semu (S), daya aktif $(P), \quad \varphi$ sudut beda fasa gelombang tegangan dan gelombang arus pada phasecal menggunakan library EmonLib.h, daya reaktif (Q) dan faktor daya (PF).

5. Kondisi jika nilai faktor daya kurang dari 0,85 sebagai nilai konstanta $\cos \varphi$ yang ingin dicapai maka langkah selanjutnya menghitung nilai reaktansi kapasitif $\left(X_{c}\right)$, menghitung nilai $C$ (capacitor), memilih nilai kapasitor yang tersedia, melakukan perhitungan daya reaktif kapasitor $\left(Q_{c}\right)$, melakukan perhitungan daya reaktif total $\left(\mathrm{Q}_{\text {total }}\right)$, melakukan perhitungan daya semu yang kedua $\left(\mathrm{S}_{2}\right)$ dan melakukan perhitungan faktor daya yang kedua $\left(\mathrm{PF}_{2}\right)$. Jika kondisi faktor daya sudah terpenuhi $\geq$ 0,85 maka tidak kembali menghitung nilai reaktansi kapasitor $\left(X_{c}\right)$, menghitung nilai $C$ (capacitor), daya reaktif kapasitor $\left(\mathrm{Q}_{\mathrm{c}}\right)$, daya reaktif total $\left(Q_{\text {total }}\right)$, daya semu yang kedua $\left(S_{2}\right)$ dan faktor daya yang kedua $\left(\mathrm{PF}_{2}\right)$.

6. LCD akan menampilkan informasi dari data yang sudah diolah dengan menampilkan nilai tegangan (V), arus (I), daya aktif $(P)$, daya semu (S), daya reaktif $(\mathrm{Q})$, dan faktor daya (PF).

7. Setiap perubahan beban induktif yang diuji, alur program mikrokontroler tetap melakukan looping program seperti prosedur nomor 2 .

\section{HASIL DAN PEMBAHASAN}

4.1. Hasil Pengujian Alat dengan Lampu TL sebelum Perbaikan Faktor Daya

Hasil data pengujian didapat dari data yang ditampilkan pada LCD. Hasil data pengujian beban lampu TL sebelum perbaikan faktor daya dapat ditunjukkan pada Tabel 1.

\subsection{Hasil Pengujian Alat dengan Lampu TL setelah Perbaikan Faktor Daya}

Hasil data pengujian didapat dari data yang ditampilkan pada LCD. Hasil data pengujian beban lampu TL setelah perbaikan faktor daya dapat ditunjukkan pada Tabel 2.

\subsection{Hasil Pengujian}

Hasil pengujian beban lampu TL sebelum perbaikan faktor daya dan setelah perbaikan faktor daya menggunakan alat perbaikan faktor daya otomatis dapat ditunjukkan melalui grafik batang pada Gambar 10.

Tabel 1. Hasil Data Pengujian Beban Lampu TL sebelum Perbaikan Faktor Daya 


\begin{tabular}{|l|c|c|c|c|c|c|}
\hline $\begin{array}{c}\text { Beban } \\
\text { Lampu TL }\end{array}$ & $\begin{array}{c}\text { Input } \\
\text { Tegangan } \\
\text { (V) }\end{array}$ & $\begin{array}{c}\text { Input } \\
\text { Arus } \\
\text { (A) }\end{array}$ & $\begin{array}{c}\text { Daya } \\
\text { Semu } \\
\text { (VA) }\end{array}$ & $\begin{array}{c}\text { Daya } \\
\text { Aktif } \\
\text { (W) }\end{array}$ & $\begin{array}{c}\text { Daya } \\
\text { Reaktif } \\
\text { (VAR) }\end{array}$ & $\begin{array}{c}\text { Faktor } \\
\text { Daya }\end{array}$ \\
\hline $1 \times 18$ watt & 223 & 0,32 & 71 & 34,93 & 64 & 0,49 \\
\hline $2 \times 18$ watt & 224 & 0,62 & 135 & 62,43 & 123 & 0,46 \\
\hline $3 \times 18$ watt & 223 & 0,95 & 210 & 92,73 & 189 & 0,44 \\
\hline $4 \times 18$ watt & 223 & 1,27 & 280 & 120,50 & 253 & 0,43 \\
\hline $5 \times 18$ watt & 223 & 1,58 & 349 & 147,93 & 316 & 0,42 \\
\hline
\end{tabular}

Tabel 2. Hasil Data Pengujian Beban Lampu TL setelah Perbaikan Faktor Daya

\begin{tabular}{|c|c|c|c|c|c|c|c|}
\hline $\begin{array}{c}\text { Beban } \\
\text { Lampu TL }\end{array}$ & $\begin{array}{c}\text { Input } \\
\text { Tegangan } \\
\text { (V) }\end{array}$ & $\begin{array}{c}\text { Input } \\
\text { Arus } \\
\text { (A) }\end{array}$ & $\begin{array}{c}\text { Daya } \\
\text { Semu } \\
\text { (VA) }\end{array}$ & $\begin{array}{c}\text { Daya } \\
\text { Aktif } \\
\text { (W) }\end{array}$ & $\begin{array}{c}\text { Daya } \\
\text { Reaktif } \\
\text { (VAR) }\end{array}$ & $\begin{array}{c}\text { Faktor } \\
\text { Daya }\end{array}$ & $\begin{array}{c}\text { C } \\
\text { (MF) }\end{array}$ \\
\hline $1 \times 18$ watt & 223 & 0,16 & 36 & 32,39 & 16 & 0,90 & 4 \\
\hline $2 \times 18$ watt & 223 & 0,29 & 64 & 57,56 & 28 & 0,90 & 8 \\
\hline $3 \times 18$ watt & 223 & 0,41 & 92 & 82,64 & 40 & 0,90 & 12 \\
\hline $4 \times 18$ watt & 223 & 0,54 & 120 & 107,30 & 53 & 0,90 & 16 \\
\hline $5 \times 18$ watt & 223 & 0,66 & 148 & 133,37 & 64 & 0,90 & 20 \\
\hline
\end{tabular}

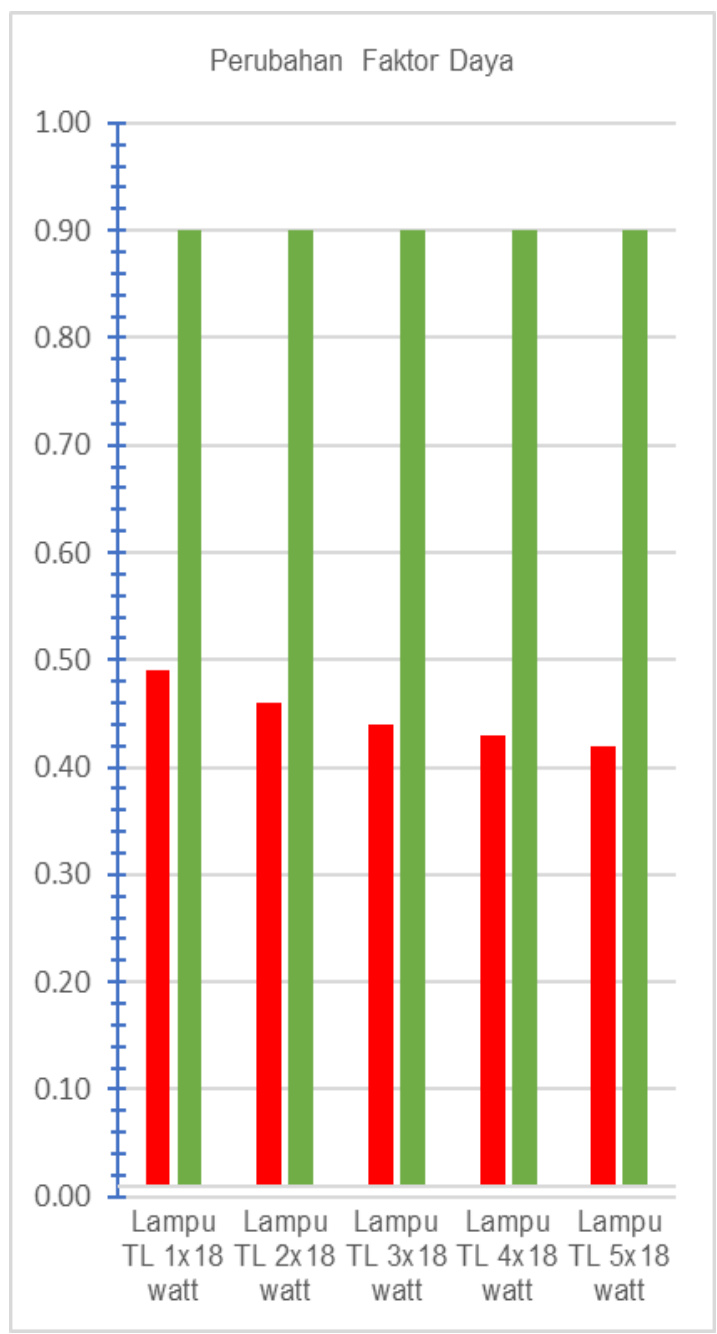

Gambar 10. Grafik Batang Perubahan sebelum Perbaikan Faktor Daya dan setelah Perbaikan Faktor Daya

\section{KESIMPULAN DAN SARAN}

\subsection{Kesimpulan}

Adapun simpulan berdasarkan hasil pengujian yang telah dilakukan pada rancang bangun kapasitor bank otomatis berbasis mikrokontroler ATmega 328P untuk perbaikan faktor daya yaitu :

1. Hasil pengujian dengan menggunakan beban induktif setiap lampu TL 1×18 watt dibutuhkan sebuah kapasitor $4 \mu \mathrm{F}$ untuk memperbaiki faktor daya beban menjadi 0,90 .

2. Hasil pengujian menunjukkan sebelum dan setelah perbaikan faktor daya berdampak pada perubahan input arus, daya semu, daya aktif dan daya reaktif pada setiap beban lampu TL.

\subsection{Saran}

Berikut saran untuk pengembangan prototype dari rancang bangun kapasitor bank berbasis ATmega 328P untuk perbaikan faktor daya yaitu :

1. Penambahan jumlah kapasitor untuk dapat memperbaiki faktor daya beban dengan nilai yang bervariasi.

2. Penambahan tampilan kondisi leading dan lagging yang dapat ditampilkan pada LCD.

\section{DAFTAR PUSTAKA}

[1] Asrul Syafrianto, Rancang Bangun Alat Untuk Perbaikan Faktor Daya Pada Beban Dinamis 1 Fase dan Monitoring Daya Dengan LCD Grafik. 2012; 2(1): 1.

[2] Ahmad Bukhari, Perbaikan Power Factor pada Konsumen Rumah Tangga Menggunakan Kapasitor Bank. 2012; 3(1): 1-2.

[3] Khadafi Alland, Efrita Z Afrah, Perancangan Kebutuhan Kapasitor Bank Untuk Perbaikan Faktor Daya pada Line Mess I di PT. Bumi Lamongan Sejati (WBL). 2013; 2(1): 2.

[4] Cekmas Cekdin, Taufik Barlian. Rangkaian Listrik. Yogyakarta: CV Andi Offset. 2013: 74-75.

[5] Pujiono, Rangkaian Listrik. Yogyakarta: Graha Ilmu. 2013: 320-322.

[6] Mohamad Ramadhani. Rangkaian Listrik. Bandung: Erlangga. 2008: 276.

[7] Tony $\mathrm{R}$ Kuphaldt. Lesson In Electric Circuits Volume II - AC. 2007: 352.

[8] Margiono Abdillah. Merakit Kapasitor Bank Untuk Jaringan Listik. Pontianak: Yayasan Kemajuan Teknik. 2015: 26.

[9] Jazi Eko Isyanto. Pengantar Elektronika dan Instrumentasi. Yogyakarta: Andi. 2014: 8-12. 